\title{
Influence of the $\mathrm{Mo}_{10} \mathrm{Ni}_{3} \mathrm{C}_{3} \mathrm{~B}$ phase on the hardness and fracture toughness of Mo-Ni-C-B cermet: experimental and theoretical study
}

\author{
A. O. Boev ${ }^{\dagger, 1,2}$, D. O. Poletaev ${ }^{3}$, A. I. Kartamyshev ${ }^{1,2}$, M. V. Boeva ${ }^{3}$, T. N. Vershinina ${ }^{4}$ \\ †antonboev@tdtu.edu.vn \\ ${ }^{1}$ Division of Computational Physics, Institute for Computational Science, Ton Duc Thang University, \\ Ho Chi Minh City, 758307, Vietnam \\ ${ }^{2}$ Faculty of Electrical \& Electronics Engineering, Ton Duc Thang University, Ho Chi Minh City, 758307, Vietnam \\ ${ }^{3}$ Belgorod State National Research University, 85 Pobedy St., Belgorod, 308015, Russia \\ ${ }^{4}$ Joint Institute for Nuclear Research, 6 Joliot-Curie St., Dubna, 141980, Russia
}

\begin{abstract}
The high productivity of the cutting material is fully determined by its properties, especially the structure and phase composition. A whole range of materials with different physical and mechanical properties can be obtained by controlling these parameters for alloys of the same system. Cermets are materials that combine the high temperature resistance and hardness of ceramics and ductility of metals. Cermets based on the Mo-Ni-B system are promising materials in applications to cutting processing. Earlier, in this system doped with carbon, a new $\mathrm{\kappa}$-phase $\mathrm{Mo}_{10} \mathrm{Ni}_{3} \mathrm{C}_{3} \mathrm{~B}$ with hexagonal $\mathrm{P} 63 / \mathrm{mmc}$ crystal structure was detected. We obtained the decreasing of hardness and comparable values of the fracture toughness of $\mathrm{Mo}_{2} \mathrm{NiB}_{2}-\mathrm{Ni}$ cermets due to the formation of $\mathrm{Mo}_{10} \mathrm{Ni}_{3} \mathrm{C}_{3} \mathrm{~B}$ phase. To understand the effect of the $\mathrm{Mo}_{10} \mathrm{Ni}_{3} \mathrm{C}_{3} \mathrm{~B}$ phase on the mechanical properties of the cermet, first-principles calculations were applied to investigate the elastic, electronic, and thermodynamic properties of this phase. Its mechanical and anisotropic properties were calculated based on the obtained elastic constants. Additionally, for a better understanding of the nature of interatomic bonding, an analysis of the electron localization function (ELF), calculated from first principles, was performed. We found that the $\mathrm{Mo}_{10} \mathrm{Ni}_{3} \mathrm{C}_{3} \mathrm{~B}$ phase had a $42 \%$ lower hardness and increased ductility compared to the $\mathrm{Mo}_{2} \mathrm{NiB}_{2}$ boride, which is expressed in the value of the bulk modulus-shear modulus ratio above the brittleviscous transition. As follows from the results of the ELF analysis, a possible reason for this is the more isotropic nature of interatomic bonds, which indicates their higher degree of metallicity.
\end{abstract}

Keywords: boride based cermet, density functional theory, elastic moduli, fracture toughness.

УДК: 538.951

\section{Влияние фазы $\mathrm{Mo}_{10} \mathrm{Ni}_{3} \mathrm{C}_{3} \mathrm{~B}$ на твердость и ударную вязкость Mo-Ni-C-B кермета: экспериментальное и теоретическое исследование}

\author{
Боев А. О. ${ }^{\dagger, 1,2}$ Полетаев Д. О. ${ }^{3}$, Картамышев А. И., ${ }^{1,2}$, Боева М. В. ${ }^{3}$, Вершинина Т.Н. ${ }^{4}$ \\ ${ }^{1}$ Отдел вычислительной физики, Институт вычислительных наук, Университет Тон Дык Тханг, \\ Хошимин, 758307, Вьетнам \\ ${ }^{2}$ Факультет электротехники и электроники, Университет Тон Дык Тханг, Хошимин, 758307, Вьетнам \\ ${ }^{3}$ Белгородский государственный национальный исследовательский университет, \\ ул. Победы 85, Белгород, 308015, Россия \\ ${ }^{4}$ Объединенный Институт Ядерных Исследований, ул. Жолио-Кюри, 6, Дубна, 141980, Россия
}

Производительность режущих материалов определяется их свойствами, которые зависят от структуры фазового состава. Контроль этих параметров в рамках одного элементного состава позволяет создавать материалы с разными физико-механическими свойствами. Керметы - это материалы, в которых сочетаются высокотемпературные характеристики и твердость керамики, а также пластические свойства металлов. Керметы на основе системы Мо-Ni-B применяются в производстве режущего инструмента. В нашей недавней работе было обнаружено в системе Mo-Ni-B, 
легированной углеродом, выделение новой к-фазы $\mathrm{Mo}_{10} \mathrm{Ni}_{3} \mathrm{C}_{3} \mathrm{~B}$, которая имеет гексагональную кристаллическую структуру с группой симметрии Р63/mmc. В настоящей работе было экспериментально установлено, что выделение фазы $\mathrm{Mo}_{10} \mathrm{Ni}_{3} \mathrm{C}_{3} \mathrm{~B}$ приводит к снижению твердости кермета $\mathrm{Mo}_{2} \mathrm{NiB}_{2}-\mathrm{Ni}$ при сохранении трещиностойкости на прежнем уровне. Для установления влияния новой фазы $\mathrm{Mo}_{10} \mathrm{Ni}_{3} \mathrm{C}_{3} \mathrm{~B}$ на механические свойства кермета нами было проведено комплексное теоретическое исследование упругих, электронных и термодинамических свойств данной фазы. Механические и упругие свойства были оценены на основе упругих характеристик фазы, рассчитанных в рамках теории функционала плотности. Кроме этого, для лучшего понимания характера межатомных взаимодействий, был проведен анализ функции локализованных электронов (ФЛЭ), которая также была рассчитана в рамках теории функционала электронной плотности. Мы обнаружили, что фаза $\mathrm{Mo}_{10} \mathrm{Ni}_{3} \mathrm{C}_{3} \mathrm{~B}$ имеет на $42 \%$ более низкую твердость и повышенную пластичность в сравнении с боридом $\mathrm{Mo}_{2} \mathrm{NiB}_{2}$. Это выражается в величине отношения модуля всестороннего сжатия к модулю сдвига выше значения хрупко-вязкого перехода. Как следует из результатов анализа ФЛЭ, возможной причиной этого является более изотропный характер межатомных связей, что говорит об их более высокой степени металличности.

Ключевые слова: кермет на основе борида, теория функционала плотности, модули упругости, ударная вязкость.

\section{Introduction}

Modern mechanical engineering is distinguished by the use of new tool materials with high cutting properties. These materials include cermets. This type of material is characterized by high processing efficiency, extended service life and increased cutting speed. Due to the combination of such characteristics as high strength, reduced brittleness, and fracture toughness, cermets can be used to process a fairly wide range of materials: cast irons, hardened steels, etc. [1]. The economic efficiency of their use in production is associated with a reduction in the time spent on the technological process itself and the replacement of grinding operations with cutting. Also, cost reduction can be achieved through the use of cheaper raw materials for the manufacture of cutting tools.

The development of technologies in the field of cutting processing directly depends on the design of new tool materials with higher physical and mechanical properties. Cermets based on the Mo-Fe-B and Mo-Ni-B systems are one of the promising and not yet widely used materials $[2,3]$. The solid phases are presented by $\mathrm{Mo}_{2} \mathrm{FeB}_{2}$ and $\mathrm{Mo}_{2} \mathrm{NiB}_{2}$ borides, and the metal matrix acts as a binder. These materials, according to a few published data, have an excellent combination of mechanical properties, wear resistance and corrosion resistance. And since the composition of these cermets does not include expensive tungsten, their development also is also economically feasible.

The performance of a cutting tool equipped with cermet inserts is determined by its structural parameters. And the development of the technology for the production of these materials is based on the identification of general patterns in the formation of the structure and phase composition at each stage of obtaining materials. Although the history of the creation of cermets of the $\mathrm{Mo}_{2} \mathrm{FeB}_{2}-\mathrm{Fe}$ and $\mathrm{Mo}_{2} \mathrm{NiB}_{2}-\mathrm{Ni}$ type goes back more than a decade, there is a clear lack of experimental data on the influence of doping and sintering conditions on the structure and phase composition, physicomechanical properties, and tribological properties of these materials.

Recently we reported [4] on the formation of a new phase in a Mo-Ni-B-C system during liquid phase reactive sintering of high purity powders of molybdenum, nickel and boron carbide. Its crystal structure was determined to be hexagonal $\mathrm{P} 63 / \mathrm{mmc}$ (Pearson symbol hP34). The energy of formation of a new phase was calculated using the density functional theory method, and it was shown that the crystal lattice of the ordered $\mathrm{Mo}_{10} \mathrm{Ni}_{3} \mathrm{C}_{3} \mathrm{~B}$ phase corresponds to the most equilibrium configuration. It was found that, in the metal sublattice of the $\mathrm{Mn}_{3} \mathrm{Al}_{10}$-type, only octahedral (6g) positions are occupied by carbon atoms, while trigonal-prismatic voids are filled with boron atoms. It was also shown in [4] that the stabilization of the $\mathrm{Mo}_{10} \mathrm{Ni}_{3} \mathrm{C}_{3} \mathrm{~B}$ phase is possible only in the presence of boron. Thus, the obtained data on the crystal structure indicate that the $\mathrm{Mo}_{10} \mathrm{Ni}_{3} \mathrm{C}_{3} \mathrm{~B}$ phase can be assigned to $\kappa$-phases. $\kappa$-phases belong to the octahedral phases of Novotny [5]. For compounds of this type, the general formula $\mathrm{M}_{9+x} \mathrm{M}_{4-x}^{\prime} \mathrm{XX}_{3}^{\prime}$ ( $x$ can be either more or less than 0 ) is proposed in [6]. M positions can be occupied by $\mathrm{Hf}, \mathrm{Zr}, \mathrm{W}, \mathrm{Mo}$, and Ti. Atoms of Mo, W, Re, Os, Cr, Mn, Fe, Co, Ni, Ta, Nb, V or $\mathrm{Cu}$ can be in positions of $\mathrm{M}^{\prime}$. Trigonal-prismatic voids can contain both transition metal atoms and non-metal atoms of the third group. So, $\mathrm{X}$ can be presented by atoms B, O, As, S, $\mathrm{Si}, \mathrm{P}, \mathrm{Ge}$ and so on. $\mathrm{X}^{\prime}$ atoms in the octahedral voids can be presented by carbon or oxygen.

There are few published data on the physical and mechanical properties of $\kappa$-phases. Nevertheless, now it is known that they are quite hard, brittle materials with metal conductivity [7]. Since the volume fraction of the $\mathrm{Mo}_{10} \mathrm{Ni}_{3} \mathrm{C}_{3} \mathrm{~B}$ phase in the cermet of Mo-Ni-B-C system studied in [4] was $\approx 27 \%$, its presence should have an effect on the properties of the material as a whole. This article presents a study of the effect of $\mathrm{Mo}_{10} \mathrm{Ni}_{3} \mathrm{C}_{3} \mathrm{~B}$ on the mechanical properties of Mo-Ni-B-C cermet. The experimental section includes hardness and fracture toughness tests of samples with and without the $\kappa$-phase. Density functional theory (DFT) calculations were carried out to reinforce the results of mechanical tests. Although DFT can't help to study mechanical properties, such as hardness and fracture toughness, directly, because it does not consider real samples with 1D-3D defects, it can obtain elastic properties of the studied phases, which correlate with the mechanical ones well enough. Thus, the theoretical section includes a DFT study of elastic and mechanical properties of $\mathrm{Mo}_{10} \mathrm{Ni}_{3} \mathrm{C}_{3} \mathrm{~B}$ and a comparative analysis of the electronic structure of $\mathrm{Mo}_{10} \mathrm{Ni}_{3} \mathrm{C}_{3} \mathrm{~B}$ and $\mathrm{Mo}_{2} \mathrm{NiB}_{2}$ to understand their different mechanical properties. 


\section{Materials and methods}

High purity powders of molybdenum, nickel and boron carbide $\left(\mathrm{B}_{4} \mathrm{C}\right)$ were used as raw materials for the production of two cermet samples with the chemical composition (wt.\%) 69.9Mo-23.3Ni-5.3B-1.5C (1) and $67.6 \mathrm{Mo}-26.1 \mathrm{Ni}-4.9 \mathrm{~B}-1.4 \mathrm{C}$ (2). A green compact with a diameter $22 \mathrm{~mm}$ and a height of $8 \mathrm{~mm}$ was produced by axial pressing at $100 \mathrm{MPa}$. A compacted sample was sintered in a vacuum of $1.3 \cdot 10^{-2} \mathrm{~Pa}$ at $1280^{\circ} \mathrm{C}$. For metallographic examination, the sample was prepared by a two-step polishing procedure using a LaboPol-5 rotary polishing machine (Struers): first, grinding with silicon carbide paper, then grinding with a diamond suspension on polishing cloth.

Scanning electron microscopy (SEM) investigations in the back-scatter mode were carried out on a Quanta 600 FEG equipped with a system for energy dispersive spectrometry (EDS). X-ray diffraction (XRD) analysis was performed at room temperature using an ARL X'TRA diffractometer with $\mathrm{Cu}_{\mathrm{K} \alpha}$-radiation. Quantitative phase analysis was performed by using the Rietveld extended program Maud [8]. The HRA hardness was measured using a standard Rockwell hardness measuring device (600 MRD InstronWolpert Wilson Instruments) with a load of $60 \mathrm{kgf}$. Determination of the fracture toughness of the investigated materials was fulfilled by the Palmqvist method [9]. A distance of $1 \mathrm{~mm}$ between indentations was kept to avoid overlapping effects. The indentation load was $60 \mathrm{kgf}$. Lengths of the cracks were measured using light optical microscopy (Olympus GX71).

Density functional theory (DFT) [10] was used for the first-principles calculations in this work. The Vienna ab initio simulation package (VASP) [11] and the high-throughput python-based package SIMAN [12] were attracted for this purpose. The exchange-correlation energy was evaluated by the generalized gradient approximation (GGA) within Perdew-Burke-Ernzerhof (PBE) functional [13]. The cutoff energy of the plane-wave basis was set to $350 \mathrm{eV}$. Smoothing the Fermi level was carried out with a smearing width of $0.2 \mathrm{eV}$. The grid of k-points in the Brillouin zone was chosen with a minimum distance between the points $0.2 \AA^{-1}$. The relaxation of the atomic positions and the supercell volume until the maximum force acting on the atoms is less than $50 \mathrm{meV} / \AA$ with the conjugate-gradient method were used to obtain an optimized geometry. Elastic constants were calculated via a stress-strain method realized in the VASP. Following equation was used for the calculation of the formation energy:

$$
E_{f}=E(N)-\sum_{i} \mu_{i} n_{i}
$$

where $E(N)$ is the energy of supercell consisting of $N$ atoms, $\mu$ is the chemical potential of $i$-element and $n$ is the number of $i$-element in the supercell. The dynamical stability of the $\mathrm{Mo}_{10} \mathrm{Ni}_{3} \mathrm{C}_{3} \mathrm{~B}$ phase was examined by using the harmonic phonon model implemented in the PHONOPY code [14], as it was made in [15].

\section{Results and discussion}

Fig. 1 shows the microstructure of $\mathrm{Mo}_{2} \mathrm{NiB}_{2}-\mathrm{Ni}$ cermets doped with carbon. As can be seen, the following phases can be observed in the structure: a solid solution based on nickel (dark phase), boride $\mathrm{Mo}_{2} \mathrm{NiB}_{2}$ (dark gray phase), $\kappa$-phase $\mathrm{Mo}_{10} \mathrm{Ni}_{3} \mathrm{C}_{3} \mathrm{~B}$ and/or carbide $\mathrm{Mo}_{2} \mathrm{C}$ (light gray phases). According to the X-ray diffraction data, the two cermets, studied in this paper, mainly differ in the content of the last two phases. In cermet 1 , only $\mathrm{Mo}_{2} \mathrm{C}$ carbide is observed, while cermet 2 contains both carbide and $\kappa$-phase are contained. The compositions of the considered samples are listed in Table 1.

Hardness measurements showed that the formation of $\kappa-\mathrm{Mo}_{10} \mathrm{Ni}_{3} \mathrm{C}_{3} \mathrm{~B}$ in the cermet leads to a decrease in hardness from 15.5 to $12.0 \mathrm{GPa}$ and a slight increase in the stress intensity factor $\mathrm{K}_{1 \mathrm{c}}$ from 9.8 to $10.4 \mathrm{MNm}^{-3 / 2}$.

According to our previous work [4], the $\mathrm{Mo}_{10} \mathrm{Ni}_{3} \mathrm{C}_{3} \mathrm{~B}$ phase has a hexagonal crystal structure with $\mathrm{P} 63 / \mathrm{mmc}$ space group (See Fig. S1, Supplementary Material). The formation enthalpy of $\mathrm{Mo}_{10} \mathrm{Ni}_{3} \mathrm{C}_{3} \mathrm{~B}$ is negative and its value is about $-5.9 \mathrm{eV}$ per unit cell, which means the thermodynamic stability of the considered phase with respect to pure components. Dynamical stability of $\kappa-\mathrm{Mo}_{10} \mathrm{Ni}_{3} \mathrm{C}_{3} \mathrm{~B}$ was further studied using DFT obtained phonon spectra. Calculated phonon dispersion curves of our phase show, that structure of the $\mathrm{Mo}_{10} \mathrm{Ni}_{3} \mathrm{C}_{3} \mathrm{~B}$ phase is dynamically stable because no imaginary phonon frequencies are found (See Fig. S2, Supplementary Material). Therefore, the considered structure of the $\mathrm{Mo}_{10} \mathrm{Ni}_{3} \mathrm{C}_{3} \mathrm{~B}$ phase is thermodynamically and dynamically stable. Also, we provide some electronic and thermodynamic properties of $\mathrm{Mo}_{10} \mathrm{Ni}_{3} \mathrm{C}_{3} \mathrm{~B}$ in Supplementary Materials.

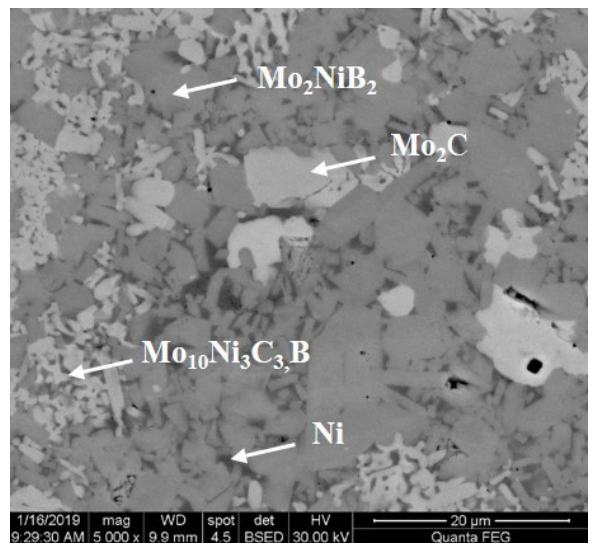

b

Fig. 1. SEM microstructure images of Mo-Ni-B-C cermets: sample 1 (a); sample 2 (b). 
The mechanical properties of the $\mathrm{Mo}_{10} \mathrm{Ni}_{3} \mathrm{C}_{3} \mathrm{~B}$ phase have been obtained through a set of elastic constants of the hexagonal $\mathrm{Mo}_{10} \mathrm{Ni}_{3} \mathrm{C}_{3} \mathrm{~B}$ phase calculated by DFT (summarized in Table 2 in comparison with $\mathrm{Mo}_{2} \mathrm{NiB}_{2}$ and $\mathrm{Mo}_{2} \mathrm{C}$ phases). We additionally checked the $\mathrm{Mo}_{10} \mathrm{Ni}_{3} \mathrm{C}_{3} \mathrm{~B}$ phase through the criteria of mechanical stability for a hexagonal structure, which are given in [16], and obtained its mechanical stability.

Bulk modulus, shear modulus, Young's modulus and Poisson's ratio were estimated according to Hooke's law and the Voigt-Reuss-Hill (VRH) model, and the Vickers hardness (HV) was calculated according to the empirical formula [19]. Also, the very important characteristics of mechanical properties are their anisotropy factors. The values of the universal anisotropy factor $\left(\mathrm{A}^{\mathrm{U}}\right)$ and the anisotropy factor of the shear modulus $\left(\mathrm{A}_{\mathrm{G}}\right)$, which are associated with plastic deformation, have been calculated. Details of all calculations are collected in Supplementary Materials. The calculated mechanical properties are listed in Table 3.

We found that $\mathrm{Mo}_{2} \mathrm{NiB}_{2}$ had the highest value of hardness, and $\mathrm{Mo}_{10} \mathrm{Ni}_{3} \mathrm{C}_{3} \mathrm{~B}$ had the lowest one. According to the phase analysis, the experimentally studied cermets are characterized by the equal amount of a binder phase based on a nickel solid solution, while differing in the volume fractions of hard phases.

It is known, the mechanical properties of a composite depend on the mechanical properties of the constituting phases, their volume fractions, and morphology. Since the $\kappa$-phase precipitates as dispersed particles with sizes substantially smaller than one of the $\mathrm{Mo}_{2} \mathrm{C}$ carbide, an increase in hardness should be observed in the case of comparable mechanical properties of the $\kappa$-phase and carbide. But a decrease in the hardness of the composite is observed in the experiment. Two factors could contribute to this:

1. a decrease in the volume fraction of boride $\mathrm{Mo}_{2} \mathrm{NiB}_{2}$,

2. low hardness of the $\kappa$-phase.

Pugh's ratio can be used to indicate the ductility of a material [20]. The shear modulus $G$ represents resistance to plastic deformation, while bulk modulus $B$ reflects resistance to fracture. Critical value $B / G=1.75$ conventionally divided materials into brittle and ductile ones; the higher the $B / G$ value means the increased ductility. Table 3 demonstrates

Table 1. Phase composition of $\mathrm{Mo}_{2} \mathrm{NiB}_{2}-\mathrm{Ni}$ cermets.

\begin{tabular}{|c|c|c|c|c|}
\hline Cermet & $\mathrm{Mo}_{2} \mathrm{NiB}_{2}$ & $\mathrm{Ni}-\mathrm{FCC}$ & $\mathrm{Mo}_{2} \mathrm{C}$ & $\mathrm{Mo}_{10} \mathrm{Ni}_{3} \mathrm{C}_{3} \mathrm{~B}$ \\
\hline 1 & $72 \pm 2$ & $8 \pm 2$ & $20 \pm 2$ & - \\
\hline 2 & $65 \pm 2$ & $12 \pm 2$ & $12 \pm 2$ & $11 \pm 2$ \\
\hline
\end{tabular}

that the plasticity increases in the following sequence: $\mathrm{Mo}_{2} \mathrm{NiB}_{2}, \mathrm{Mo}_{10} \mathrm{Ni}_{3} \mathrm{C}_{3} \mathrm{~B}$, and $\mathrm{Mo}_{2} \mathrm{C}$. Thus, a slight increase in crack resistance of cermet 2 in comparison with cermet 1 can additionally be caused by the $\kappa$-phase formation.

We analyzed the bonding character of hard $\mathrm{Mo}_{2} \mathrm{NiB}_{2}$ and softer $\mathrm{Mo}_{10} \mathrm{Ni}_{3} \mathrm{C}_{3} \mathrm{~B}$ phases for a better understanding of differences in hardness values. Electron localization functions (ELF) were calculated to estimate the type of bonds for both phases. For $\mathrm{Mo}_{2} \mathrm{NiB}_{2}$ we obtained a strong covalent bond between two neighboring $\mathrm{B}$ atoms, which are clearly visible on (100) slice of 2D ELF iso-surfaces as a red color area between B-B pairs (Fig. 2) and mean strong electron localization due to covalent bond formation.

As for the softer $\mathrm{Mo}_{10} \mathrm{Ni}_{3} \mathrm{C}_{3} \mathrm{~B}$, the strong covalent bonding is absent there. It can be seen from Fig. 3 that the electron density is localized on the non-metallic atoms $(\mathrm{B}, \mathrm{C})$; meanwhile, there is no bonding between $\mathrm{B}$ and $\mathrm{C}$ (slice (110)). B atoms show the five electron localized areas: two vertical ones in the (100) slice and three horizontal ones in the (001) slice. Also, there is the absence of strong bonding with surrounding atoms. There are just green areas of electron localization directed to the groups of $\mathrm{Ni}$ atoms ((001) slice in Fig. 3).

The universal anisotropy factor $\mathrm{A}^{\mathrm{U}}$ and the anisotropy factor of shear modulus $A_{G}$ (Table 3 ) demonstrate that both $\mathrm{A}^{\mathrm{U}}$ and $\mathrm{A}_{\mathrm{G}}$ for the $\mathrm{Mo}_{10} \mathrm{Ni}_{3} \mathrm{C}_{3} \mathrm{~B}$ compound are less than that for $\mathrm{Mo}_{2} \mathrm{NiB}_{2}$ ( 0.08 vs 0.13 and 0.002 vs 0.013 , respectively), which indicates more isotropic character of bonding, reflecting its metallic type. Also, according to the numerical estimates of TDOS and ELF, the $\mathrm{Mo}_{10} \mathrm{Ni}_{3} \mathrm{C}_{3} \mathrm{~B}$ phase has a positive value of the Cauchy pressure $\mathrm{C}_{12}-\mathrm{C}_{44}=88 \mathrm{GPa}$. The positive Cauchy pressure indicates that the nature of the bonding is predominantly metallic [21].

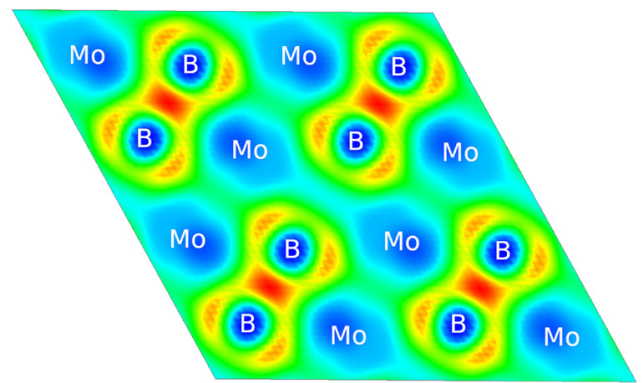

Fig. 2. (Color online) 2D iso-surfaces of electron localization function of $\mathrm{Mo}_{2} \mathrm{NiB}_{2}$ phase. (100) surface slice.

Table 2. The calculated elastic constants of cermet phases in units of GPa.

\begin{tabular}{|c|c|c|c|c|c|c|c|c|c|}
\hline Phase & $\mathrm{C}_{11}$ & $\mathrm{C}_{12}$ & $\mathrm{C}_{13}$ & $\mathrm{C}_{22}$ & $\mathrm{C}_{23}$ & $\mathrm{C}_{33}$ & $\mathrm{C}_{44}$ & $\mathrm{C}_{55}$ & $\mathrm{C}_{66}$ \\
\hline $\mathrm{Mo}_{10} \mathrm{Ni}_{3} \mathrm{C}_{3} \mathrm{~B}$ & 491 & 219 & 197 & 492 & 197 & 535 & 131 & 142 & 141 \\
\hline $\mathrm{Mo}_{2} \mathrm{NiB}_{2}[17]$ & 535 & 196 & 221 & 558 & 154 & 498 & 179 & 236 & 172 \\
\hline $\mathrm{Mo}_{2} \mathrm{C}[18]$ & 506 & 138 & 193 & - & - & 474 & 184 & - & 132 \\
\hline
\end{tabular}

Table 3. Mechanical properties of $\mathrm{Mo}_{10} \mathrm{Ni}_{3} \mathrm{C}_{3} \mathrm{~B}, \mathrm{Mo}_{2} \mathrm{NiB}_{2}$ and $\mathrm{Mo}_{2} \mathrm{C}$ (unit for elastic moduli and hardness: GPa). Anisotropy factors of $\mathrm{Mo}_{10} \mathrm{Ni}_{3} \mathrm{C}_{3} \mathrm{~B}$ and $\mathrm{Mo}_{2} \mathrm{NiB}_{2}$.

\begin{tabular}{|c|c|c|c|c|c|c|c|c|c|}
\hline Phase & $\mathrm{B}$ & $\mathrm{G}$ & $\mathrm{E}$ & $\mathrm{HV}$ & $v$ & $\mathrm{~B} / \mathrm{G}$ & $\mathrm{H} / \mathrm{E}$ & $\mathrm{A}^{\mathrm{U}}$ & $\mathrm{A}_{\mathrm{G}}$ \\
\hline $\mathrm{Mo}_{10} \mathrm{Ni}_{3} \mathrm{C}_{3} \mathrm{~B}$ & 304.8 & 141.8 & 368.3 & 11.8 & 0.299 & 2.150 & 0.032 & 0.085 & 0.002 \\
\hline $\mathrm{Mo}_{2} \mathrm{NiB}_{2}[17]$ & 303.1 & 183.1 & 457.3 & 20.4 & 0.249 & 1.655 & 0.045 & 0.132 & 0.013 \\
\hline $\mathrm{Mo}_{2} \mathrm{C}[18]$ & 281.8 & 153.8 & 390.4 & 15.7 & 0.269 & 1.832 & 0.040 & - & - \\
\hline
\end{tabular}



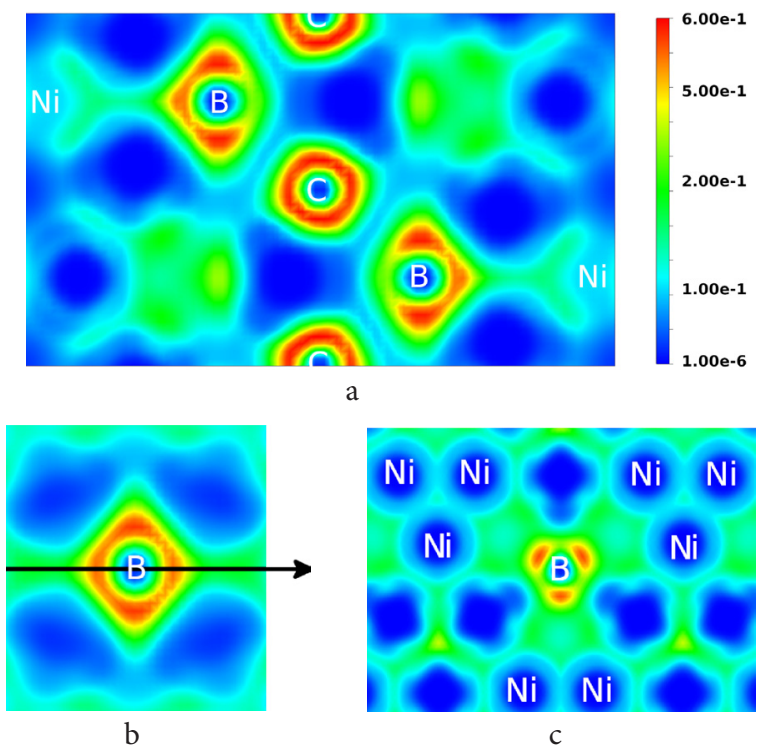

Fig. 3. (Color online) 2D iso-surfaces of electron localization function of $\mathrm{Mo}_{10} \mathrm{Ni}_{3} \mathrm{C}_{3} \mathrm{~B}$ phase. (110) surface slice (a); 2D isosurfaces of electron localization function near $\mathrm{B}$ atom in $\mathrm{Mo}_{10} \mathrm{Ni}_{3} \mathrm{C}_{3} \mathrm{~B}$ phase: (100) view (black arrow shows the slice of (001) plane) (b); (001) view (c).

The study of $\mathrm{W}_{9} \mathrm{Al}_{3} \mathrm{CoC}_{3} \mathrm{~B}$ single crystals, given in [7], also shows that this $\mathrm{K}$-phase has relatively low hardness values. It was also shown in this paper that micro-hardness of $\mathrm{W}_{9} \mathrm{Al}_{3} \mathrm{CoC}_{3} \mathrm{~B}$ seems to be more or less isotropic, despite the high anisotropy of the crystal structure.

Transition metal carbides, which have partial metallic nature, show in metal-ceramic composites a stronger bond with metal matrix than more covalent bonded ceramics [22]. In [23] $\mathrm{Ni}-16 \mathrm{Al}-8 \mathrm{Cr}-1 \mathrm{Zr}-0.1 \mathrm{~B}$ matrix with particles of $\mathrm{TiC}, \mathrm{Al}_{2} \mathrm{O}_{3}$ and $\mathrm{TiB}_{2}$ reinforcements prepared by powder metallurgy route has been investigated. It was shown that $\mathrm{TiC}$ carbide has excellent bond integrity, which leads to much higher elastic moduli and yield strength compared to that with $\mathrm{Al}_{2} \mathrm{O}_{3}$ and $\mathrm{TiB}_{2}$. It was explained in [22] by the metallic nature of $\mathrm{TiC}$ and the strong interaction of Ti with both $\mathrm{Ni}$ and $\mathrm{Al}$.

Thus, it can be assumed that the $\kappa$-phase $\mathrm{Mo}_{10} \mathrm{Ni}_{3} \mathrm{C}_{3} \mathrm{~B}$, which predominantly has metallic bonding, has a strong interaction with the metal matrix, and it can lead to a greater improvement in Young's modulus, yield, and ultimate tensile strength values over those of the matrix material. Tensile strength is also notable in the case of metallic bonding at interfaces as they can withstand higher strains [22].

\section{Conclusion}

In this paper, experimental and theoretical investigation of the $\kappa-\mathrm{Mo}_{10} \mathrm{Ni}_{3} \mathrm{C}_{3} \mathrm{~B}$ phase and its influence on the hardness and fracture toughness of Mo-Ni-B-C cermet were conducted. Based on the results, the following conclusions can be made: stable.

1. $\mathrm{k}-\mathrm{Mo}_{10} \mathrm{Ni}_{3} \mathrm{C}_{3} \mathrm{~B}$ is thermodynamically and mechanically

2. $\kappa$-phase has the lowest hardness values in comparison with $\mathrm{Mo}_{2} \mathrm{NiB}_{2}$ and $\mathrm{Mo}_{2} \mathrm{C}$. Its formation in the Mo-Ni-B-C cermet leads to a decrease in the hardness of the composite.

3. The nature of the bonding in the $\mathrm{Mo}_{10} \mathrm{Ni}_{3} \mathrm{C}_{3} \mathrm{~B}$ phase is predominantly metallic. This determines its ability to plastic deformation, which, as a result, can affect the fracture toughness of $\mathrm{Mo}_{2} \mathrm{NiB}_{2}-\mathrm{Ni}$ cermet as a whole.

Supplementary material. The online version of this paper contains supplementary material available free of charge at the journal's Web site (lettersonmaterials.com).

\section{References}

1. L. Laperriere, G. Reinhart. CIRP encyclopedia of production engineering. Springer, Berlin, Heidelberg (2014). Crossref

2. M. B. Ivanov, T.N. Vershinina, V.V. Ivanisenko. Materials Science and Engineering: A. 763, 138117 (2019). Crossref

3. K. Takagi. Journal of Solid State Chemistry. 179, 2809 (2006). Crossref

4. T.N. Vershinina, A. O. Boev, M.B. Ivanov. Vacuum. 172, 109034 (2020). Crossref

5. F. Benesovsky. Modern Developments in Powder Metallurgy. Springer, Boston, MA (1966) pp. 175-189 Crossref

6. M. Komai, Y. Yamasaki, K. Takagi. Solid State Phenomena. 25, 531 (1992). Crossref

7. D. Kotzott, H. Hillebrecht. Journal of alloys and compounds. 494, 88 (2010). Crossref

8. L. Lutterotti, S. Matthies, H. Wenk. Newsletter of the CPD. 21, 14 (1999).

9. S. Sheikh, R. M'Saoubi, P. Flasar, M. Schwind, T. Persson, J. Yang, L. Llanes. International Journal of Refractory Metals and Hard Materials. 49, 153 (2015). Crossref

10. W. Kohn, L. Sham. Physical Review. 140 A, 1133 (1965). Crossref

11. G. Kresse, J. Furthmüller. Computational Materials Science. 6, 15 (1996). Crossref

12. D. Aksyonov, S. Fedotov, K. Stevenson, A. Zhugayevych. Computational Materials Science. 154, 449 (2018).

13. J. Perdew, K. Burke, M. Ernzerhof. Physical review letters. 77 (18), 3865 (1996). Crossref

14. L. Chaput, A. Togo, I. Tanaka, G. Hug. Physical Review B. 84 (9), 094302 (2011). Crossref

15. Y. Pan, W. Guan. Inorganic chemistry. 57, 6617 (2018). Crossref

16. J. Nye.Physical properties of crystals: their representation by tensors and matrices. Oxford university press (1985).

17. Y. Jian, Z. Huang, X. Liu, J. Xing. Results in Physics. 15, 102698 (2019). Crossref

18. Y. Luo, H. Guo, J. Guo, W. Yang. Materials. 11 (12), 2577 (2018). Crossref

19. X. Chen, H. Niu, D. Li, Y.Li. Intermetallics. 19, 1275 (2011). Crossref

20. S. Pugh. The London, Edinburgh, and Dublin Philosophical Magazine and Journal of Science. 45, 823 (1954). Crossref

21. D. Pettifor. Materials science and technology. 8, 345 (1992). Crossref

22. R. Mitra, Y. Mahajan. Bulletin of Materials Science. 18, 405 (1995). $\underline{\text { Crossref }}$

23. G. Fuchs. Metal \& Ceramic Matrix Composites: Processing, Modeling \& Mechanical Behavior. Warrendale, Pa. (1990) pp. 391-400 (1990). 